\title{
Erratum to: Cumulative energy demand in LCA: the energy harvested approach
}

\author{
Rolf Frischknecht $^{1}$ • Franziska Wyss $^{1}$ • Sybille Büsser Knöpfel ${ }^{1}$ • Thomas Lützkendorf ${ }^{2}$ • \\ Maria Balouktsi ${ }^{2}$
}

Published online: 2 March 2016

(C) Springer-Verlag Berlin Heidelberg 2016

\section{Erratum to: Int J Life Cycle Assess}

DOI: 10.1007/s11367-015-0897-4

\section{Correction}

Due to a misinterpretation of an information source, the characterisation factor of geothermal energy within the approach 'CED energy statistics approach' was wrongly reported and applied. This affected the case study results using this approach. In this paper, the correct tables and figures are displayed.

The characterisation factor of geothermal energy in the approach 'CED energy statistics' is 1.0 , and not 7.0 (see Table 3).
The cumulative energy demand, renewable of the residential building Rautistrasse according to the 'CED energy statistics' approach, is $76 \mathrm{MJ}$ wood-eq. $/ \mathrm{m}^{2} \mathrm{a}$, and the total cumulative energy demand is $421 \mathrm{MJ}$ oil-eq./ $\mathrm{m}^{2} \mathrm{a}$ (see Table 6).

Over the whole life cycle of the building, the use phase causes $70 \%$ of the cumulative energy demand according to the approach 'CED energy statistics' (Table 7), followed by the manufacturing and construction phase $(17 \%)$, the replacement $(11 \%)$ and the end of life stage $(1 \%)$.

The online version of the original article can be found at http://dx.doi.org/ 10.1007/s11367-015-0897-4.

Rolf Frischknecht

frischknecht@treeze.ch

treeze Ltd, Kanzleistrasse 4, CH-8610 Uster, Switzerland

2 Karlsruher Institut für Technologie (KIT) Ökonomie und Ökologie des Wohnungsbaus (ÖÖW), Kaiserstraße 12,

76131 Karlsruhe, Germany 
Table 3 Characterisation factors for the five approaches CED standard, CED energy statistics, CED uranium low, CED uranium high and CED VDI 4600

\begin{tabular}{|c|c|c|c|c|c|c|}
\hline Energy sources from ecoinvent data $v 2.2+$ & Unit & CED standard & $\begin{array}{l}\text { CED energy } \\
\text { statistics }\end{array}$ & $\begin{array}{l}\text { CED uranium } \\
\text { low }\end{array}$ & $\begin{array}{l}\text { CED uranium } \\
\text { high }\end{array}$ & $\begin{array}{l}\text { CED VDI } \\
4600\end{array}$ \\
\hline \multicolumn{7}{|l|}{ Nonrenewable, fossil } \\
\hline Coal, brown & $\mathrm{MJ} / \mathrm{kg}$ & $9.90 \mathrm{E}+00$ & $8.10 \mathrm{E}+00$ & $9.90 \mathrm{E}+00$ & $9.90 \mathrm{E}+00$ & $8.10 \mathrm{E}+00$ \\
\hline Coal, hard & $\mathrm{MJ} / \mathrm{kg}$ & $1.91 \mathrm{E}+01$ & $1.84 \mathrm{E}+01$ & $1.91 \mathrm{E}+01$ & $1.91 \mathrm{E}+01$ & $1.84 \mathrm{E}+01$ \\
\hline Gas, mine, off-gas, process, coal mining/kg & $\mathrm{MJ} / \mathrm{kg}$ & $4.98 \mathrm{E}+01$ & $4.53 \mathrm{E}+01$ & $4.98 \mathrm{E}+01$ & $4.98 \mathrm{E}+01$ & $4.53 \mathrm{E}+01$ \\
\hline Gas, mine, off-gas, process, coal mining/m3 & $\mathrm{MJ} / \mathrm{m} 3$ & $3.98 \mathrm{E}+01$ & $3.62 \mathrm{E}+01$ & $3.98 \mathrm{E}+01$ & $3.98 \mathrm{E}+01$ & $3.62 \mathrm{E}+01$ \\
\hline Gas, natural $/ \mathrm{m} 3$ & $\mathrm{MJ} / \mathrm{m} 3$ & $3.83 \mathrm{E}+01$ & $3.48 \mathrm{E}+01$ & $3.83 \mathrm{E}+01$ & $3.83 \mathrm{E}+01$ & $3.48 \mathrm{E}+01$ \\
\hline Gas, off-gas, oil production, in ground & $\mathrm{MJ} / \mathrm{m} 3$ & $3.98 \mathrm{E}+01$ & $3.62 \mathrm{E}+01$ & $3.98 \mathrm{E}+01$ & $3.98 \mathrm{E}+01$ & $3.62 \mathrm{E}+01$ \\
\hline Oil, crude & $\mathrm{MJ} / \mathrm{kg}$ & $4.58 \mathrm{E}+01$ & $4.32 \mathrm{E}+01$ & $4.58 \mathrm{E}+01$ & $4.58 \mathrm{E}+01$ & $4.32 \mathrm{E}+01$ \\
\hline \multicolumn{7}{|l|}{ Nonrenewable, nuclear } \\
\hline Uranium & $\mathrm{MJ} / \mathrm{kg}$ & $5.60 \mathrm{E}+05$ & $4.70 \mathrm{E}+05$ & $1.80 \mathrm{E}+05$ & $7.72 \mathrm{E}+05$ & $5.60 \mathrm{E}+05$ \\
\hline \multicolumn{7}{|l|}{ Nonrenewable, biomass } \\
\hline Wood, primary forest, standing & $\mathrm{MJ} / \mathrm{m} 3$ & $1.08 \mathrm{E}+04$ & $4.32 \mathrm{E}+03$ & $1.08 \mathrm{E}+04$ & $1.08 \mathrm{E}+04$ & $4.32 \mathrm{E}+03$ \\
\hline \multicolumn{7}{|l|}{ Renewable, biomass } \\
\hline Wood, hardwood, standing & $\mathrm{MJ} / \mathrm{m} 3$ & $1.28 \mathrm{E}+04$ & $5.12 \mathrm{E}+03$ & $1.28 \mathrm{E}+04$ & $1.28 \mathrm{E}+04$ & $5.12 \mathrm{E}+03$ \\
\hline \multicolumn{7}{|l|}{ Renewable, wind, solar, geothermal } \\
\hline Energy, geothermal, converted & $\mathrm{MJ} / \mathrm{MJ}$ & $1.00 \mathrm{E}+00$ & $1.00 \mathrm{E}+00$ & $1.00 \mathrm{E}+00$ & $1.00 \mathrm{E}+00$ & $1.00 \mathrm{E}+00$ \\
\hline Energy, kinetic (in wind), converted & $\mathrm{MJ} / \mathrm{MJ}$ & $1.00 \mathrm{E}+00$ & $9.30 \mathrm{E}-01$ & $9.30 \mathrm{E}-01$ & $1.00 \mathrm{E}+00$ & $3.72 \mathrm{E}+00$ \\
\hline Energy, solar, converted & $\mathrm{MJ} / \mathrm{MJ}$ & $1.00 \mathrm{E}+00$ & $9.35 \mathrm{E}-01$ & $9.35 \mathrm{E}-01$ & $1.00 \mathrm{E}+00$ & $6.01 \mathrm{E}+00$ \\
\hline \multicolumn{7}{|l|}{ Renewable, water } \\
\hline Energy, potential (in hydropower reservoir), converted & $\mathrm{MJ} / \mathrm{MJ}$ & $1.00 \mathrm{E}+00$ & $9.50 \mathrm{E}-01$ & $9.50 \mathrm{E}-01$ & $1.00 \mathrm{E}+00$ & $1.19 \mathrm{E}+00$ \\
\hline
\end{tabular}

Values are given in MJ oil-eq. per reference unit

Table 6 Cumulative energy demand of manufacturing and construction, replacement and use phase and end of life of the residential property 'Rautistrasse' in the city of Zürich

\begin{tabular}{lllllll}
\hline Indicator & Unit & CED standard & CED energy statistics & CED uranium low & CED uranium high & CED VDI 4600 \\
\hline Total & MJ oil-eq./m² & 477 & 421 & 336 & 554 & 478 \\
Nonrenewable & MJ oil-eq./m² & 351 & 307 & 212 & 428 & 340 \\
Renewable & MJ wood-eq. $/ \mathrm{m}^{2} \mathrm{a}$ & 126 & 76 & 124 & 126 & 138 \\
\hline
\end{tabular}

Values are given per square metre of energy reference area and per year. The totals are calculated assuming 1 MJ oil-eq. equals 1 MJ wood-eq. The five different CED approaches are described in the 'Review of existing approaches' section

Table 7 Share of cumulative energy demand of manufacturing and construction, replacement, use and end of life of the residential property 'Rautistrasse' in the city of Zürich

\begin{tabular}{|c|c|c|c|c|c|}
\hline Life stage & CED standard (\%) & $\begin{array}{l}\text { CED energy } \\
\text { statistics (\%) }\end{array}$ & $\begin{array}{l}\text { CED uranium } \\
\text { low }(\%)\end{array}$ & $\begin{array}{l}\text { CED uranium } \\
\text { high }(\%)\end{array}$ & CED VDI $4600(\%)$ \\
\hline Manufacturing and construction & 17 & 17 & 22 & 15 & 17 \\
\hline Replacement & 12 & 11 & 15 & 11 & 11 \\
\hline Use & 70 & 70 & 61 & 73 & 71 \\
\hline End of life & 1 & 1 & 2 & 1 & 1 \\
\hline
\end{tabular}




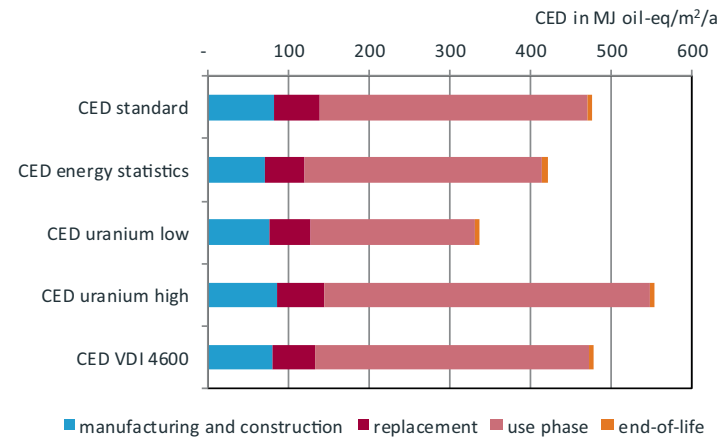

Fig. 1 Left Cumulative energy demand of the life cycle of the building Rautistrasse in Zürich, differentiating between manufacturing and construction, replacement, use and end of life of the building. Right Cumulative energy demand of the use phase of the building, providing

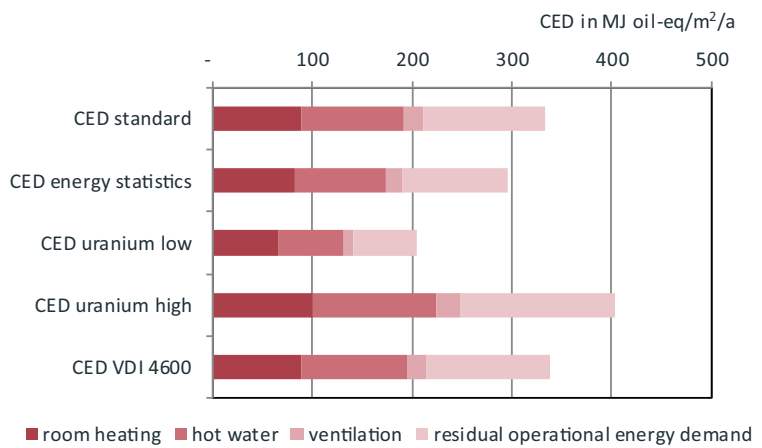

room heating, hot water, ventilation, light and auxiliary operational energy. All values are given per square metre of energy reference area and per year. The five different CED approaches are described in the 'Review of existing approaches' section
Fig. 2 Cumulative energy demand of the use phase of the building Rautistrasse in Zürich, showing the different energy resources. $P E$ primary energy, $n r$ nonrenewable, $r$ renewable

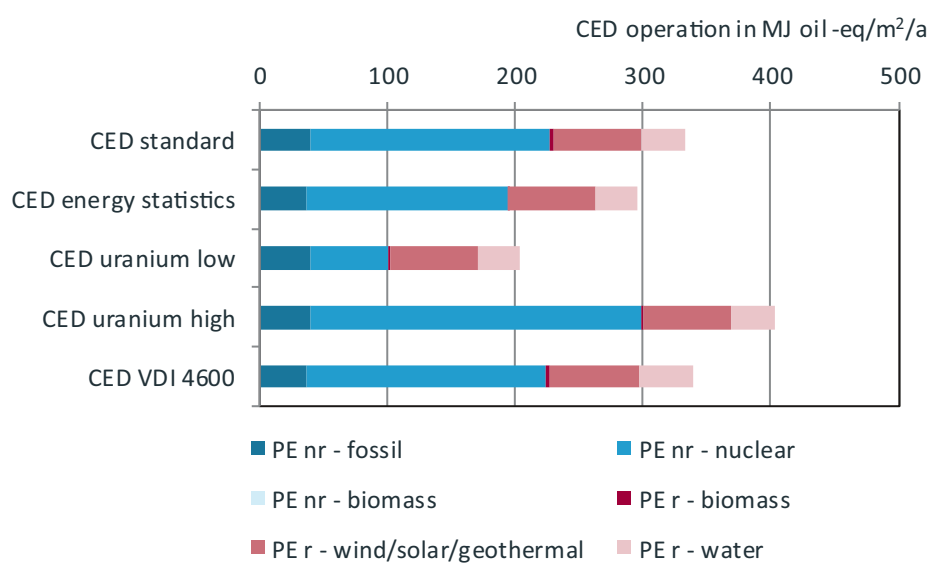

Acknowledgments We wish to thank Lothar Rausch, ÖkoInstitut e.V., Berlin, Germany, who pointed us the error in the published version of this paper. 